\title{
Investment Decisions and Investor Experience in Choosing Financial Technology (Fintech) Services:
}

\author{
Peer-To-Peer Lending \\ Bernika Setiawan*, Yanuar Andrianto, Fitri Safira \\ Sekolah Tinggi Manajemen PPM \\ Jakarta, Indonesia \\ *BER@ppm-manajemen.ac.id
}

\begin{abstract}
The expansion of digital technology in financial sector making the opportunity for the emergence of the products to meet people's financial needs. P2PL is one of the emergence product which present as an instrument of investment by providing loans. This research aims to describe the investor perspective of P2PL as an alternative instrument for investment. This is done by phenomenological approach in interviewing several investors in P2PL related to motivation in choosing P2PL as an investment instrument and exploring the investor's investment experience in P2PL. Based on the findings of the content analysis on the collected data, this research found that investors assessed that P2PL had a better value in terms of returns and risk levels compared to other investment instruments. P2PL also provides good convenience in terms of access to business processes that are used which allows all people of any background to be able to invest in the platform provided. Past investment experience is important, especially during the decision-making process in the investment journey in P2PL. Therefore, based on the findings of this research, researcher try to describe the investment decision making process into an investors' journey in P2PL.
\end{abstract}

Keywords-P2PL, investment, motivation, decision making, phenomenological approach, investment journey

\section{INTRODUCTION}

Peer-to-Peer Lending (P2PL) is the development of financial products and services using technology. P2PL is a financial technology (FinTech) product. FinTech as utilizing the development of information technology in improving services in the financial industry [1]. The development of FinTech greatly facilitates public access to financial products and services. This facility is then expected to drive an increase in financial inclusion which is targeted to reach $75 \%$ in 2019.

P2PL exists as an alternative of financing and investment that is quite popular in Indonesia. In Indonesia, P2PL funding is referred to as online communal funding. P2PL company growth is significant in the last three years. As of November 2019, there have been 144 P2PL companies which have been licensed and registered in Indonesia. The presence of P2PL was quickly exploited by people who needed fast loans. The number of borrowers calculated based on the number of accounts increased by $266.71 \%$ from the previous year, so that in November 2019, the number of borrowers was 15.9 million borrower accounts.
In this study, investors are defined as lenders or those who channel funds to those in need through the P2PL platform. From the funding investor will get the benefit in the future from the interest. The increase in the number of investor accounts experienced a very significant increase of $178.62 \%$ in November 2019 from the previous year.

OJK see that the presence of P2PL has many benefits to the community especially because it provides an opportunity for people who want to invest in an easier way and get higher returns when compared to the returns obtained in other investment instruments in the capital market [1]. Investors themselves are one of the keys to success in the sustainability of the P2PL industry, especially when investors have managed to find a suitable P2PL as a substitute alternative or complementary alternative to other investment facilities owned. P2PL has great potential to become the investment vehicle that must be considered by the investor [2]

Many previous studies on P2PL have focused on factors that influence the desires and success of channelling funds to P2PL and how to make effective decisions that are based on P2PL that exist outside Indonesia. Specifically, this research studies more deeply about investor behaviour in investing in P2PL in Indonesia. This study examines investors' (lenders) practice in making investment decisions starting from choosing P2PL as an alternative investment instrument to selecting and evaluating the investments made.

\section{LITERATURE REVIEW}

\section{A. Peer-to-Peer Landing (P2PL)}

The importance of decision making by investors, there have been studies on lending decision making by investors such as a person's motivation to invest in $\mathrm{P} 2 \mathrm{PL}$ to research on the determinants of investment returns from lending. A person's motivation in investing in P2PL generally considers two things: the benefits received and the risks that need to be borne by the investors themselves [3]. Financial aspects such as return on investment and security in investing are among the things considered in choosing the P2PL platform [4-6]. There are other aspects such as social aspects that also encourage a person to invest in P2PL even though it is not a priority motivation especially for institutions that prioritize profits $[7,8]$. Every decision made by an investor is very dependent on the information provided by the P2PL platform [9] 
The decision is made based on the trust held by investors both to the borrowers and to the P2PL platform itself. This trust has a very important role in an online transaction such as that which takes place in P2PL and influences the willingness of investors to channel loans $[3,10]$. The more people who know or become more familiar with the P2PL platform, the more confidence and desire of someone to invest in the P2PL platform [11].

Other studies also classify trust into several categories. As described in Yang et al research, classifying trust into three broad groups is trust based on the system provided by the platform, trust based on the first impression of the investor in P2PL when there is no prior investment experience, and trust based relationship social and emotional or affective [6]. That research found that several factors influence investor confidence in providing loans such as information provided by the platform, investor awareness or recognition of a platform, and trust in borrowers themselves. Platform reputation is also a significant factor in increasing consumer confidence in the P2PL platform, especially for investors who have no investment experience in previous P2PL [12], investors who have invested, the experience they have and the information provided by the $\mathrm{P} 2 \mathrm{PL}$ platform will also strengthen the reputation of a P2PL platform [13]. Therefore, the role of the P2PL platform to collect, process and distribute information to related parties is very important [14].

In the process, the investor also makes the decision to choose the borrower to fund. This process is influenced by various information presented. Based on the concept of financial information, the information provided is hard information and soft information [15]. Both of this information will then be used by investors to assess the creditworthiness of borrowers and this is the crucial investing phase in P2PL [6].

Previous studies have also made a simulation of an investor's mechanism in choosing the borrower to be funded. The relationship of an investor and borrower is described as a bipartite graph where investors can diversify their funds to many borrowers and a loan application can be funded by many investors [16]. As one of them conducted by Wei and Lin who tried to develop models and simulate the mechanism for selecting loan proposals by investors to find mechanisms that can provide benefits to both borrowers and investors (lenders) [17].

\section{B. Financial Behaviour}

Jahanzeb and Muneer in their research stated that although investments have been made based on forecasting, reviewing investment performance and taking into account market times there is still a difference between the actual investment value and that calculated [18]. In other words, investors also make irrational decisions when conducting information. Economists also approve of it. The irrational aspects that influence the decision making process can be explained through behavioural finance theory and this has a negative correlation with EMH theory [19]. Financial behaviour is a psychological approach to financial science in the process of making financial decisions. Lintner defines financial behaviour as a science that studies how individuals interpret and react to information to make investment decisions [20].

There are several theories that explain financial behaviour which are herding theory, anchoring theory, regret theory and prospect theory. Herding theory illustrates the behaviour of investors who are very dependent on the opinions of other investors [21]. Whereas Anchoring theory explains the behaviour of investors who depend heavily on a data or information obtained without taking into account the accuracy of the source [22]. Investors also often make investment decisions in a state of fear and greed. Although the theory generally says that buying assets at low prices and selling them at high prices, in fact investors tend to buy assets that are on the rise whose value in the future will decline. This is one example of Herding Theory.

Many investors tend to avoid feeling disappointed because of the losses caused by the decline in investment value. This is explained in Regret Theory, where investors may retain a detrimental asset rather than sell it and get more losses [23]. When experiencing this, investors also tend to avoid the detrimental industries. These theories of financial behaviour are not used for forecasting, but studied to understand the phenomena in financial markets.

\section{METHOD}

\section{A. Study Design}

This research is a qualitative study in order to understand and explore the motivation and investment process of investors in P2PL in Indonesia. Through a phenomenological approach, researchers will describe the investment experience of the informants. This research consists of four stages including collecting data, compiling and preparing data for analysis, processing data and content analysis. In practice, this step does not take place in a linear but more interactive because one stage is related to the other stages so that the process of processing and analysing data can go hand in hand or repeatedly.

\section{B. Participants}

The informants of this study consisted of 8 people ( 5 men and 3 women). The informant has invested in P2PL from 1 month to 1 year 9 months. Investment experience from investors is also diverse, there are those who invest on one platform to invest on 8 platforms at once. Of course this diversity allows researchers to be able to see a more complex picture of investor motivation and experience in P2PL. The number of informants was considered sufficient by the researcher based on the saturation principle.

\section{Procedure}

Information gathering by interview. The interview was divided into three parts, namely exploring the motivation and informant process in making investment decisions, then the decision making process in selecting the borrowers to be financed and the investor's assessment of the investment process that has been undertaken. The interview process lasts for an average of 35 minutes (the shortest is 17.19 minutes and 
the longest is 1 hour 7 minutes). Six of the eight informants were interviewed directly by the researcher and two other informants were interviewed by telephone because the time and distance did not allow the researcher to meet in person.

\section{Data Analysis}

The researchers coding the transcript. The process of coding is done by reviewing all available transcripts and making codes that describe information from informants. In the coding process for each transcript, the analysis process is also carried out on the meaning of the utterances from the informants, so it is very possible if there is a change from the codes given. This process is done by researchers using a qualitative data processing program, namely QDA Miner Lite. This program helps researchers make the coding process faster and more efficient and makes it easier for researchers to carry out the analysis process. Researchers also documented the process of coding and analysis in a research memo and code book.

\section{RESUlTS AND ANALYSIS}

\section{A. Motivation to Invest in P2PL}

This study found that there are six things that motivate an investor to invest in P2PL. The first three motivations are closely related to financial aspects and the other three motivations are non-financial. The first three motivations related to financial aspects in general are the same things that are considered in other investment instruments, which are return, risk and investment diversification.

The high rate of return attracts investors to invest in P2PL and become consideration for choosing the P2PL platform. These findings are consistent with what was found by Pierrakis and Collins in their research on people investing in P2PL in a case study at a Funding Circle company [4]. The rate of return is one of the key variables that encourage a person to give a loan [5]. The higher the rate of return offered, the more attractive investors will be to provide loans.

So far, P2PL is considered as a safe investment instrument by investors. The assessment is based on several factors including the value of the assets invested tend to be stable, the risk management process that minimizes the risk borne by investors, P2PL companies registered or licensed in the Financial Services Authority (OJK) and the P2PL platform has been widely used or reviewed / discussed in Indonesia.

Based on these four factors, the researcher sees that the informant has a tendency to compare the risks that occur in P2PL with the risks that generally occur in financial markets such as stocks. This is particularly indicated by security considerations that investing in P2PL does not cause impairment in assets held. However, this does not mean that it is not possible for P2PL, it's just that the possibility depends on how risk management is implemented by the P2PL company itself and how the investor processes in selecting the borrower.

Although classified as a safe investment instrument, investments made by one P2PL company with other companies have different risks depending on the operational system and the borrower. Likewise, the rate of return offered also varies depending on risk, the amount of funds invested and the loan tenor. Diversification on several instruments or on several P2PL platforms will complement each other. Investments in instruments that have a high rate of return but on the other hand also have a high risk will be balanced by investing in instruments with a lower level of return but have a smaller risk.

The other three non-financial motivations are investment ease, trust (belief) and the social impact which will be explained in detail.

1) Investment ease: One of the factors driving investors to invest in P2PL is the ease of investment systems and processes compared to other conventional investments. Investors assume that the understanding and knowledge required to invest in P2PL are relatively easier, as perceived by informant L, informant $\mathrm{J}$, informant $\mathrm{A}$ and informant $\mathrm{B}$.

This is convenience because P2PL provides information other than financial aspects about the borrowers as a means of making funding decisions. The P2PL platform provides two types of information namely "hard information" and "soft information" that can be used by investors to assess the creditworthiness of a borrower [9]. Hard information in the form of information related to the borrower's financial information, while soft information is supporting information about the borrower's profile itself such as photographs, industries involved, work performed and others.

P2PL allows investors to evaluate the creditworthiness of borrowers by considering both types of information. Therefore, investors who do not have the ability to evaluate creditworthiness as is usually done by banks, can still conduct an evaluation by utilizing the soft information. This allows all investors with or without qualified financial ability to participate, so it looks easier when compared to investments in other capital markets.

But even though it is said to be easier and simpler in investing, informant $\mathrm{K}$ believes that every investor still needs to be financially literate to truly understand each investment instrument such as P2PL. Although the risks involved in investing in P2PL are not in the form of risks of impairment of assets such as investments through shares, but this investment has its own risk in the form of defaults that may occur by borrowers. Informant $\mathrm{K}$ also said that if someone is financially literate and understands the risk of financial activities carried out, then that person will not be wrong in choosing investment instruments or financial services that are suitable for him.

FinTech products, including P2PL, study the difficulties often faced by someone in using banking services and make the experience of investors in using this product easier [24]. The ease of the investment process offered by investors is indeed a plus for P2PL, but it still needs to be treated wisely by investors. When investing, investors must be aware and know the risks of the investment activities undertaken. An understanding of the risks posed will determine investment behaviour and decisions to be made by investors by utilizing the information provided properly. 
2) Trust (belief): On the P2PL platform provided, investors and borrowers cannot communicate directly, so all transaction processes are carried out through online procedures. An investor's trust in the borrower and the P2PL platform as a mediator play a very important role in investing [10]. These beliefs are grouped into two groups of beliefs, namely specific trust based on the character of the borrower and general trust or confidence in the borrower. Confidence in general can also be referred to as a belief in borrowers that the borrowers will act cooperatively in meeting the expectations of investors. Although in P2PL investors have the opportunity to select loans to be given, investors remain unfamiliar and do not know the borrower or even do not have a history of previous transactions. In this case belief based on forecasting rather than actual history becomes normal. Likewise, as experienced by the informants, that the informant in investing has confidence in the borrowers as believed by informants $\mathrm{L}$ and $\mathrm{K}$, where there is good intention from the borrower to repay the loan.

Trust (belief) in the borrower is important in the process of investors making investment decisions. But in the end this belief will be matured with the experience experienced by investors themselves in making investments.

3) The social impact: In addition to the financial aspects underlying the investments made, investors are also quite motivated to provide social impact through investments in P2PL. The social impact given here is to help people who need funds by providing loans. On certain P2PL platforms, it has segmented its borrowing targets for certain classes such as Amartha. Amartha is a P2PL platform that focuses on micro entrepreneurs in the lowest pyramid class and also as a form of empowering women in Indonesia. Giving social impact here is one of the more values that can be given to investors in their investment activities.

Investors who have invested their money in Amartha such as informant $\mathrm{L}$, informant $\mathrm{J}$, informant $\mathrm{N}$, informant $\mathrm{T}$ and informant $\mathrm{A}$ agree that social impact is a supportive reason for choosing this platform. Even for informant $\mathrm{N}$, investing in Amartha is to provide a social impact so that the return obtained is not the most important concern as long as it is still in accordance with the desired risk.

"Yes, because it (the social impact) was because my original motive was not to make an investment and the return it's just my second motive. That's fine. I also rarely check (the platform). Maybe if it (return) becomes my initial motivate, I'll keep checking." - Informant $N$

However, the main concern is the investment provided remains in accordance with the risk appetite of each investor. Even so, social impact is not the main motivation in investing in P2PL. The motivation for social motivation will decrease in profit institutions such as P2PL [7].

\section{B. Investment Experience on P2PL}

Investor experience in investing on the P2PL platform can be simply shown in Figure 1 below. This process begins when investors feel they need another investment alternative. The presence of $\mathrm{P} 2 \mathrm{PL}$ is an investment alternative that needs to be considered. P2PL is considered attractive as an investment tool because it provides a greater return when compared to conventional investment instruments as explained in the previous motivational explanation. This is also supported by various facilities that can be felt by investors in the investment process. Through the information provided, it is possible for everyone to be able to conduct a credit worthiness assessment of the person who will be funded. This ease is also supported by technology that makes the P2PL platform user friendly and makes it easy for users to make every transaction. FinTech products and services, including P2PL therein, understand the difficulties often faced when using banking services and make all the processes that consumers will go through smooth and pleasant [24]. This ease also makes P2PL one of the right tools for people who want to learn to invest, as perceived by Informant $\mathrm{N}$ and Informant $\mathrm{B}$.

"As for the service, they sell the system. yes, the system is easier to understand for new people (in investment." Informant B

The convenience offered by the P2PL platform opens up many opportunities for people from various backgrounds to be able to participate in investing. This has become one of the added values for the P2PL platform to become an alternative investment vehicle. Like other Fintech companies, P2PL is designed not only to be an easy-to-use platform, but also to be a platform where users can meet their financial needs and desires.

Furthermore, investors also need to make a decision to choose the P2PL platform that will be used from the many P2PL platforms in Indonesia. This process is carried out by gathering information related to the P2PL platform.

In this collection process investors look for alternative platforms, the criteria used to evaluate a platform and see the quality of alternative platforms based on predetermined criteria. More and more investors know information about a platform will build investor confidence in the platform and the people who borrow through the platform [11]. In addition to obtaining information from the website, the informant also sought to obtain information from fellow investors who had made investments. The experience of investing from other investors becomes input and consideration for investors when they want to choose the P2PL platform. Even the results of recommendations from colleagues who are known to have a greater influence than the information that has been listed [9]. This happens because investors tend to have herding behaviour [21], which is an attitude that considers the information owned by others better because they have previous experience.

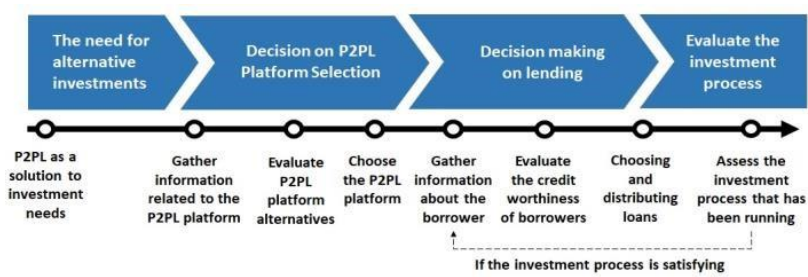

Fig. 1. Investor journey on P2PL. 
This information is taken into consideration for investors to conduct a more in-depth evaluation, especially related to the business mechanism of P2PL (table 1). The business mechanisms used on the P2PL platform in Indonesia are very diverse. The diverse business models and all aspects within them are the main attraction for each investor. Therefore, investors need to understand the business mechanics used on a platform well before finally making a decision.

Investor confidence in a P2PL platform as well as in the need to be built because the confidence that is owned will reduce anxiety in the investment process and this belief also becomes the thing that drives investors' intention to invest [6]. When investors are convinced, it doesn't take long for investors to consider investing in the P2PL platform, as experienced by the informants.

The decision making process continues to determine the borrowers registered on the platform from which the investor will channel funds. This decision-making process begins with gathering information related to the borrower provided by the platform and also taking into consideration the previous investment experience that others have. This is where P2PL as an intermediary platform has a role to collect, process and forward information to both parties [14]. Hard information and Soft information will be used by investors to evaluate the creditworthiness of borrowers. Examples of hard information such as credit history, income, debt ratio and income. While soft information is like the location of origin, photos, type of business, business sector and other information about the borrower's profile. The P2PL platform also helps investors in the process of evaluating credit worthiness by providing credit scores to borrowers that have been calculated by the P2PL platform.

After collecting information related to borrowers, investors must evaluate the creditworthiness of the borrowers to determine the borrowers. This creditworthiness assessment phase is a crucial phase in the investment process in P2PL because in conducting an assessment, investors need to consider various available information [6]. Investors arrange investments according to the criteria and risk appetite of each. Behaviour and perspective of investors in choosing greatly affect the decisions to be made. This study found that borrower credit scores were first considered and used to form alternative groups of borrowers.

Investors also assess the credit worthiness of borrowers from information that has been obtained. Benchmarks used between one investor and another vary according to risk appetite and expected returns. The experience and information possessed by investors will be taken into consideration for investors choosing criteria and evaluating the creditworthiness of borrowers.

Despite the research, Iyer et al states that soft information tends to be used to help investors make judgments with borrowers with low credit quality, but this study shows a different phenomenon [9]. Investors continue to use soft information as a consideration in choosing a borrower to fund even though the borrower has a high credit score.
This experience will minimize the opportunity for investors to make mistakes in decision making. This shows the tendency of investors to avoid factors that can be detrimental to the investment process as in Regret Theory [23]. In this research, investors use their experience to choose the ideal borrower's criteria that can be trusted to avoid future losses. Whether it's for investors who don't have experience or investors who have invested, past investment experience is important. Exchanging investment experience through P2PL discussion forums is very beneficial for investors.

After going through a series of investment processes, investors will conduct an evaluation of the investment process that has been running. The results of this evaluation are valuable lessons for investors in making decisions in the future. The investment process also ultimately shows the performance of a P2PL platform to users, in this case investors. Evaluation conducted at this stage will bring investors to compare their expectations with the process. Investor confidence will increase when their expectations are fulfilled and will make it continue to invest again. Even investors are willing to provide recommendations and share their experiences in investing in the P2PL. However, if the process does not meet the expectations of the investor, they can be antipathy and not continue the investment process.

\section{CONCLUSION}

$\mathrm{P} 2 \mathrm{PL}$ is an alternative investment that is calculated by investors. P2PL has its own appeal because it offers a greater rate of return when compared to conventional investment instruments. In the process, investors can choose a borrower that is done by considering the credit worthiness and risk of each borrower in accordance with the risk appetite of each investor. Information about borrowers provided by the P2PL platform allows investors to conduct credit worthiness assessments even though they do not have the usual risk analysis capabilities of banks. This makes P2PL an easy investment instrument both in terms of access and investment process and allows everyone to use it.

P2PL's diverse business mechanism becomes a characteristic and becomes its own attraction. Through the P2PL platform, investors also have a social impact for borrowers specifically on the segmentation of certain borrowers such as micro entrepreneurs in areas that are difficult to access finance or on specific lending allocations such as the need for education and health costs.

In the decision-making process, investment experience will affect the perspective of investors in making an assessment, especially when evaluating the credit worthiness of a borrower. Through this experience investor will have their own valuation criteria that are believed to be the right parameters in choosing a borrower. This experience not only benefits investors themselves but also benefits other investors who have just started investing. Discussion forums become one of the important information channels and are used by investors to be able to minimize the wrong decision making.

In the end, with all the considerations of information received by investors, investors' beliefs are the key factors that strengthen decision making, both in choosing the P2PL 
platform and choosing the borrower. This belief is built along with the ongoing investment process. When investor expectations can be met through the services provided by the P2PL platform, investors do not hesitate to continue investing even sharing this good experience with other colleagues.

\section{FURTHER RESEARCH}

The model of investment experience models in P2PL resulting from this study can be developed and tested in subsequent studies. Research on each of the stages in the decision making process as well as the factors that influence decision making as mentioned in this research can be retested quantitatively in order to increase the accuracy of the research results. The quantitative research should be carried out within the scope of investors on the P2PL platform in Indonesia. Researchers can also apply this research to different population groups in Indonesia in order to produce more comprehensive findings. The development of investor decision-making research in Indonesia will enrich and broaden the perspectives of actors and encourage the development of P2PL itself in Indonesia.

\section{REFERENCES}

[1] B. Luo and Z. Lin, "A decision tree model for herd behavior and empirical evidence from the online P2P lending market," Information Systems and e-Business Management, vol. 11, no. 1, pp. 141-160, 2011.

[2] S. Garman, R. Hampshire and R. Krishnan, A Search Theoretic Model of Person-to-Person Lending, 2008.

[3] H. Shefrin and M. Statman, "The disposition to sell winners too early and ride losers too long: Theory and evidence," Journal of Finance, vol. 40, no. 3, pp. 777-790, 1985

[4] OJK, Strategi Nasional Literasi Keuangan Indonesia (Revisit 2017). Jakarta: OJK, 2017. Retrieved from: https://www.ojk.go.id/id/beritadankegiatan/publikasi/Pages/Strategi-Nasional-Literasi-Keuangan-Ind.

[5] P. Hanafizadeh and H.R. Khedmatgozar, "The mediating role of the dimensions of the perceived risk in the effect of customers' awareness on the adoption of Internet banking in Iran," Electronic Commerce Research, vol. 12, no. 2, pp. 151-175, 2012.

[6] A.M. Weiss, N.H. Lurie and D.J. Macinnis, "Listening to Strangers: Whose Responses are Valuable, how Valuable are They, and Why?" Journal of Marketing Research, vol. 45, no. 4, pp. 425-436, 2008

[7] V. Bellotti, A. Ambard, D. Turner, C. Gossmann, K. Demkova and J.M. Carroll, "A muddle of models of motivation for using peer-to-peer economy systems," Proceedings of the 33rd Annual ACM Conference on Human Factors in Computing Systems, pp. 1085-1094, 2015.

[8] E.M. Gerber, J.S. Hui and P.Y. Kuo, "Crowdfunding: Why people are motivated to post and fund projects on crowdfunding platforms," Proceedings of the international workshop on design, influence, and social technologies: techniques, impacts and ethics, vol. 2, no. 11, pp. 10,2012

[9] M. Herzenstein, S. Sonenshein and U.M. Dholakia, "Tell me a good story and I may lend you money: The role of narratives in peer-to-pee lending decisions," Journal of Marketing Research, vol. 48, pp. S138S149, 2011

[10] D. Chen, F. Lai and Z. Lin, "A trust model for online peer-to-peer lending: a lender's perspective," Information Technology and Management, vol. 15, no. 4, pp. 239-254, 2014

[11] J. Introne, K. Levy, S. Munson, S. Goggins, R. Wash and C. Aragon, "Design, influence, and social technologies: techniques, impacts, and ethics," Proceedings of the ACM 2012 conference on Computer Supported Cooperative Work Companion pp. 9-10, 2012

[12] D. Kahneman and A. Tversky "Belief in the law of small number," Psychological Bulletin, vol. 76, no. 2, pp. 105-110, 1971

[13] M. Herzenstein, R.L. Andrews, U.M. Dholakia and E. Lyandres, "The democratization of personal consumer loans? Determinants of success in online peer-to-peer lending communities," Boston University School of Management Research Paper, vol. 14, no. 6, pp. 1-36, 2008.

[14] D. Chen, H. Lou and C. Van Slyke, "Toward an Understanding of Online Lending Intentions: Evidence from a Survey in China," Communications of the Association for Information Systems, vol. 36, 2015

[15] S.H. Kim and H.S. Park, "Effects of various characteristics of social commerce (s-commerce) on consumers' trust and trust performance," International Journal of Information Management, vol. 33, no. 2, pp. 318-332, 2013.

[16] J.M. Liberti and M.A. Petersen, "Information: Hard and Soft," SSRN Electronic Journal, 2018.

[17] Q. Wan, D. Chen and W. Shi, "Online Peer-to-peer Lending Decision Making: Model Development and Testing," Social Behavior and Personality: an international journal, vol. 44, no. 1, pp. 117-130, 2016.

[18] R. Iyer, A.I. Khwaja, E.F.P. Luttmer and K. Shue, "Screening in New Credit Markets: Can Individual Lenders Infer Borrower Creditworthiness in Peer-to-Peer Lending?" SSRN Electronic Journal, 2009

[19] W. Coffie, Behavioural Finance Theories Effecting on Individua Investor's Decision-Making (Unpublished master's thesis). University of Wolverhamption. United Kingdom, 2013.

[20] A.V. Banerjee, "A Simple Model of Herd Behavior," The Quarterly Journal of Economics, vol. 107, no. 3, pp. 797-817, 1992.

[21] X. Zeng, L. Liu, S. Leung, J. Du, X. Wang and T. Li, "A decision support model for investment on P2P lending platform," PLOS ONE, vol. 12, no. 9, e0184242, 2017.

[22] A. Jahanzeb, "Implication of behavioral finance in investment decisionmaking process," Information management and business review, vol. 4, no. 10, pp. 532-536, 2012.

[23] Y. Pierrakis and L. Collins, Banking on each other: peer-to-peer lending to business: evidence from funding circle. Nesta, 2013.

[24] R.P. Buckley and S. Webster, "FinTech in developing countries: charting new customer journeys," Journal of Financial Transformation, vol. 44, 2016. 